\title{
A Check List of Weeds in Rice Fields of Coastal Orissa, India
}

\author{
H. N. Subudhi ${ }^{1}$, S. P. Panda ${ }^{2}$, P. K. Behera ${ }^{3} \&$ Chitra Patnaik $^{4}$ \\ ${ }^{1}$ Central Rice Research Institute, Cuttack, India \\ ${ }^{2}$ P. G. Department of Botany, Utkal University, Bhubaneswar, India \\ ${ }^{3}$ Panchayat College, Baragarh, Orissa, India \\ ${ }^{4}$ P. N. College, Khurda, Orissa, India \\ Correspondence: H. N. Subudhi, Central Rice Research Institute, Cuttack 753006, India. E-mail: \\ dr_hatanath_subudhi@yahoo.co.in
}

Received: May 4, 2014 Accepted: September 10, 2014 Online Published: May 15, 2015

doi:10.5539/jas.v7n6p207 URL: http://dx.doi.org/10.5539/jas.v7n6p207

\begin{abstract}
A survey was undertaken to different rice ecologies to collect, identify and conserve the weed species as herbarium specimens in coastal districts of Orissa. In this programme, 201 angiosperm taxa and 3 pteridophytes under 146 genera belonging to 56 families were collected, identified and documented. Poaceae was the dominant family followed by Fabaceae and Cyperaceae. Families are arranged according to modified Bentham and Hooker's system of classification in the enumeration. Genus and species were arranged alphabetically under each family and genus. The number of weed species was more in upland followed by irrigated, semi deep water and deep water.Conservation strategies are also highlighted in this paper.
\end{abstract}

Keywards: exploration, weeds rice fields, Orissa, conservation

\section{Introduction}

Rice is widely grown cereal crop that feeds millions of people in world (Kumar et al., 2008). It is the most important cereal crop cultivated in wide range of habitat under varying temperature and water regime. Rice fields are one of the large and extensive fresh water ecosystem on earth.The total rice areas is about 44.6 Mha in India. These act as a ideal habitat for numerous species of aquatic, amphibious and terrestrial weeds that compete with rice crop for space and nutrients. With the dominance of rice crop, grasses, sedges and broad leaves plants are referred as weeds. Biodiversity is the key component for sustainable environment. Currently rice fields are under serious threat owing to rapid increase in human population and urbanization. This phenomenon sets the biodiversity of rice fields at stake making it necessary to take immediate step for conservation. Application of agrochemical and inorganic fertilizer is the major concern for biodiversity loss. Rice fields are the transitional ecosystem that acts as both aquatic for one part of the year and terrestrial the rest. This unique ecosystem acts as potential habitat for numerous species of biota that have adapted to the highly disturbed environment. In Orissa most of the rice fields are rainfed which means it depends on rainwater only.

During rainy season, the rice fields are full of rain water but in Rabi season the fields are completely dry, so the floral succession differs in both the season due to different water regime. Most of the aquatic plants did not appear during dry season. Rice fields are colonized by terrestrial, semiaquatic and aquatic species (Moody \& Drost, 1983). Moody (1989) reported 2049 species of weeds from 15 south-east Asian countries. Till now, no systematic survey of weed species was made in Orissa in particular and eastern India in general except some sporadic reports. For effective weed management practice, study of weed phenology and their biology is highly essential. Some sporadic reports regarding the occurrence of weeds in Orissa were made by Patnaik (1956), Tripathy and Mishra (1988), Maiti et al. (1983). Mishra and Choudhury (1996) made extensive survey of aquatic plants in different areas of Bhubaneswar in Orissa state. Subudhi et al. (2002) and Subudhi and Choudhury (2000) reported deep water weed flora and floristic diversity of weeds in Cuttack district of Orissa. Besides these, Bahar and Bhat (2012) reported rice weeds of Kashmir. Pragada and Malliboyana (2010, 2012) and Singh and Rao (1973) reported the phytosociological study rice weeds of Andhra Pradesh respectively. Realizing these, extensive survey were undertaken in seven districts of coastal Orissa in different seasons. A total 201 Angiosperm taxa and three pteridophytes were collected identified and housed in as herbarium specimen in P. G. Department of Botany, 
Utkal University Bhubaneswar. In the enumeration, families are arranged according to modified Bentham and Hooker's system of classification (1882-1883).

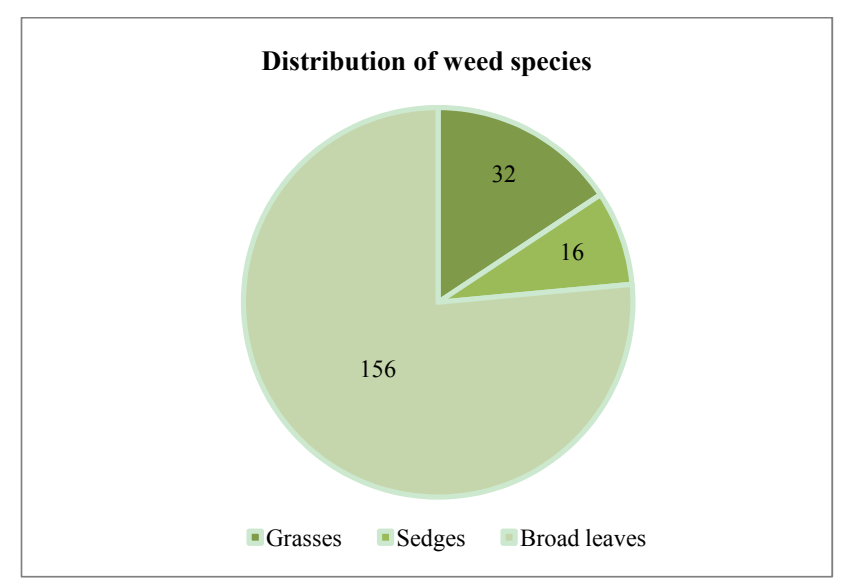

Figure 1. Distribution of weed species

\section{Material and Methods}

Field trips were undertaken regularly to different rice growing areas during Kharif and Rabi season. Weeds in upland are different from irrigated and lowlands. In irrigated, usually marshy plant are metwith. In lowlands, aquatic and submerged plants are commonly grown, in bunds, terrestrial plant are grown. The plant samples were collected with flowering and kept inside polythene bag. The detailed information regarding associate, ecology, other field characters are recorded in note book. After collection, the specimens were dried, poisoned and fixed in herbarium sheets (Jain \& Rao, 1977). The samples are identified in consultation with regional and modern flora.Information regarding utility were collected from local people. Some unidentified specimen were confirmed after matching with the herbarium at CentralNational Herbarium, Calcutta and regional herbarium at Regional Research Laboratory, Bhubaneswar. Correct name was given to each plant in consultation with the flora of British India (Bentham \& Hooker, 1882-1883; Saxena \& Brahmam, 1994; Haines, 1921-1925) and modern floras.

\subsection{Study Area}

Orissa is one of the coastal district lies in coast of Bay of Bengal.It is situated in $17^{\circ} 49^{\prime}$ to $22^{\circ} 34^{\prime} \mathrm{N}$ latitudes and $81^{\circ} 27^{\prime}$ to $87^{\circ} 29^{\prime} \mathrm{E}$ longitudes. The coastal districts are Cuttack, Puri, Bhadrak, Balasore, kendrapara, Jagatsinghpur and khurda etc. (Figure 2). These districts are having maximum rainfed areas. High rainfall occurs due to south west monsoon during the month of July and August (Figure 3).

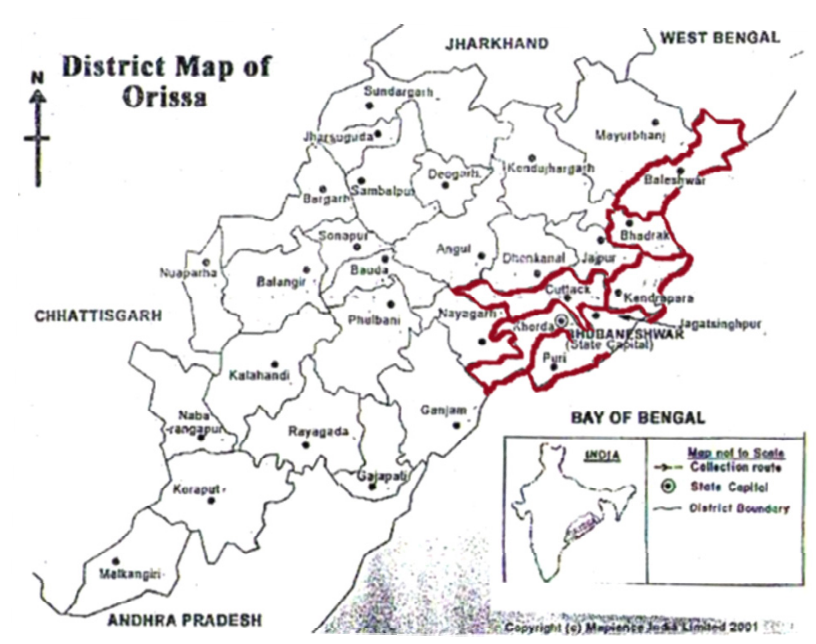

Figure 2. Study area 


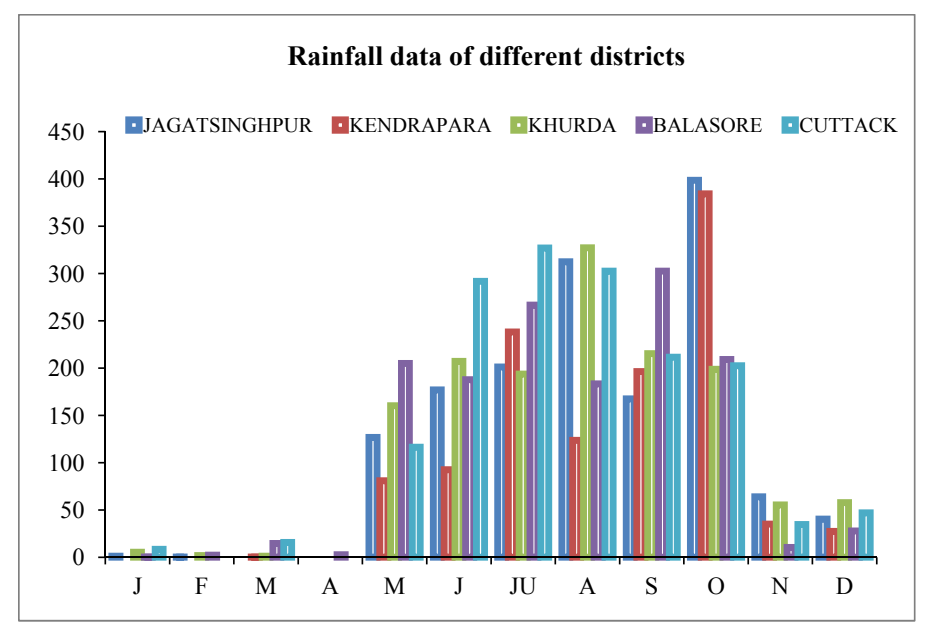

Figure 3. Rainfall data of different districts

\subsection{Climate}

Rice is the main crop in Orissa. It is grown in two seasons i.e. Kharif (June-December) and Rabi (January-May). South west monsoon is the principal source of rain contributing $80 \%$ of rainfall during kharif season. Kharif crop starts with onset of monsoon i.e. on June, the diversity of weeds is very rich in this season due high rainfall. During Rabi season, diversity is less due to less water. The average annual rainfall in Orissa is $1350.6 \mathrm{~mm}$. Maximum rainfall occurs in the month of July-October. The temperature varies from $15-44{ }^{\circ} \mathrm{C}$. December is the coldest month and May is the hottest month of the year.

\subsection{Cultural Practices}

In Orissa, most of the lands are rainfed because there is no irrigation facility and direct seeded in rainfed areas is the usually practice of the farmers. It is also economical and better suited for lowlands. After summer plough, in the month May/June, fields are broadcasted. Germination occurs after onset South west monsoon along with weeds. In July, there is heavy rainfall, which encourages the growth of weed species of different category much quicker than rice. After one month of germination, beusaning followed by laddering are the usually practices in Orissa which destroyed most of weed species. Water remains in fields up to October in lowlands, most of the hydrophytes grow in lowland as weeds, it remains up to December, there after, weed species dies. During Rabi season, other weed species appear and diversity is very less due to non availability of water. In irrigated field, the species richness is low but some dominant species occur very luxuriantly.

\section{Results and Discussion}

During exploration, 201 numbers of species under 145 genera belonging to 56 families were collected, identified and documented. The weed species are categorized 1) upland, 2) irrigated, 3) lowland, 4) saline ecology. The species are different from ecology to ecology. The number of weed species are more in upland (65) followed by irrigated (61), semi deep water (54) and deep water (21) (Figure 4). It is interesting to note that upland weeds can not beavailable in lowland/irrigated conditions. Upland weeds are having xeric adaptation due less water and flowers in August and September, whereas lowland weeds are hydrophytic adaption. These plants flower in October-December, the vegetative growth starts with onset of rainfall. 


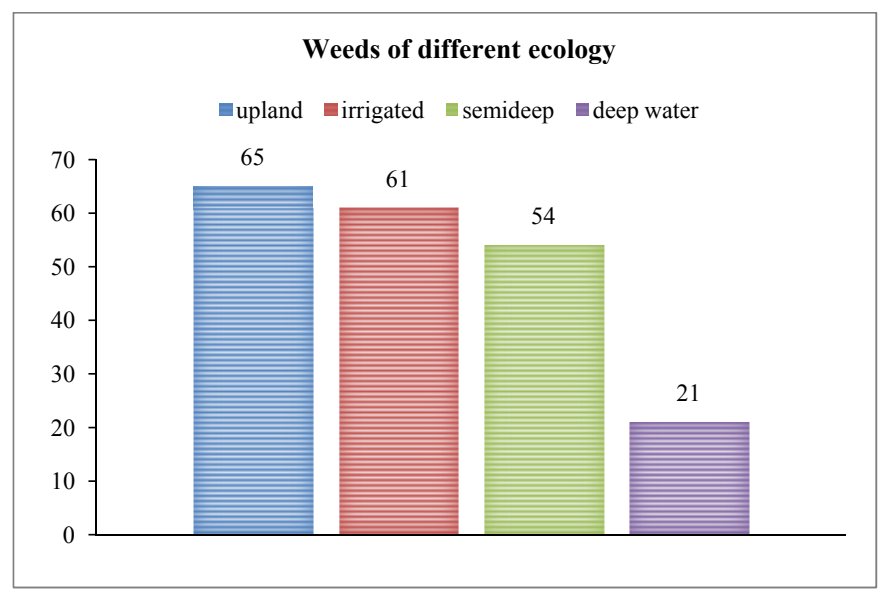

Figure 4. Weeds of different ecology

During the present survey programme a total of 201 Angiosperm species under 146 genera belonging to 56 families along with three pteridophytes. Out of 201 species, 123 species of dicots are distributed under 88 genera belonging to 40 families, while 78 monocot species spread over 57 genera under 16 families. It is interesting to note that out of 78 species of monocots 48 species are sedges and grasses, which constitute $64.97 \%$ of the total monocots. The approximate ratio of monocot and dicots species is 1:2.8. So it indicates that dicots are represented by nearly about three times than the monocots, which is represented in the Table 1 . Out of 56 families, 20 families are represented by single species. Poaceae is the first dominant family where as it is in the $2^{\text {nd }}$ and $3^{\text {rd }}$ position in the flora of Bihar and Orissa and flora of British India respectively (Figure 5). On the other hand, Fabaceae and Cyperaceae are the $2^{\text {nd }}$ and $3^{\text {rd }}$ largest family respectively.

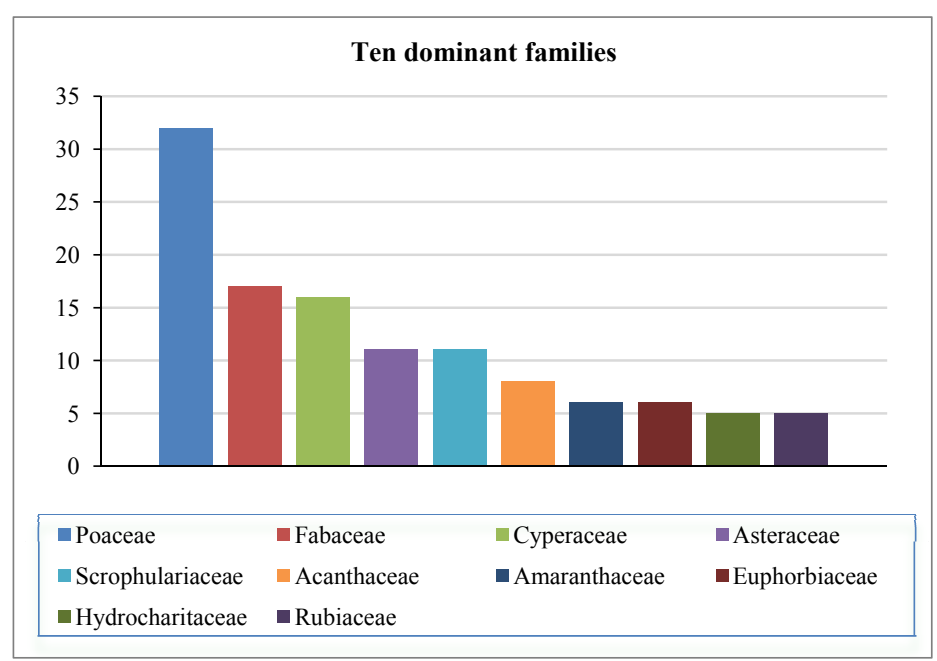

Figure 5. Ten dominant families

Table 1. Percentage of families, genera and species of dicots and monocots are represented below

\begin{tabular}{|c|c|c|c|c|c|c|}
\hline \multirow{2}{*}{ Groups } & \multicolumn{2}{|c|}{ Families } & \multicolumn{2}{|c|}{ Genera } & \multicolumn{2}{|c|}{ Species } \\
\hline & No. & $\%$ & No. & $\%$ & No. & $\%$ \\
\hline Dicotyledones & 40 & 78.76 & 88 & 75.52 & 123 & 73.73 \\
\hline Monocotyledones & 16 & 21.24 & 57 & 24.47 & 78 & 26.26 \\
\hline
\end{tabular}

Due to population growth, operation of biotic factors like conversion of agriculture land to residential complexes, application chemical, pesticide and inorganic fertilizer, the biodiversity both flora and fauna in rice fields are declining at alarming rate. Again many weed species are having potential value for food, medicine and check soil 
erosion (Oudhia, 2001). So awareness should be given to the farmers/common people to conserve the species in general and weeds in particular for future use. There are four rice ecologies namely upland, irrigated, semideep water and deep water.

\subsection{Upland Weeds}

Rice fields, where there is no standing water are called as Uplands. The plant species in uplands are having some xeric adaptation and tolerance for drought. The species germinate immediately after rain in the month of mid June. Weeds remain in the field up to Octoberor till maturity. The weed diversity is very high in this ecology. The common species are Cleome viscosa, Cleome monophylla, Argemone mexicana, Spermacoce articularis, Spermacoce pusilla, Allmania nudiflora, Celosia argentea, Aerva lanata, Sebastiana chaemelia, Scoparia dulcis. The common sedges are Bulbostylis barbata, Cyperus rotundus, Fimbristylis dichotoma, Fiurena ciliaris, etc. Similarly The grasses are Chloris barbata, Chrysopogon aciculatus, Cynodon dactylon, Dactyloctenium aegyptium, Dicanthium pertusum, Digitaria ciliaris, Eragrostis ciliaris, Imperata cylindrical, Oplismenus compositus, Chysopogon aciculatus, Perotis india.

\subsection{Irrigated Ecology}

Water is irriged at regular interval to the field, so that there is no water stress to the plant. Sometimes the field is having standing water also which promotes luxuriant weed population. The diversity is very rich but in some cases two/three species are dominant in the fields, other species are rare. The common species are Portulaca oleracea, Bergia ammaniodes, Crotalaria protrata, Desmodium triflorum, Rotala indica, Glinus oppositifolia, Dentella repens, Grangea maderaspatana, Bacopa monnieri, Oxalis corniculata, Marsilia minuta, Zornia gibbosa, Centella asiatica, Gnaphalium polycaulon, Mecadonia dianthera, Lindernia crustacea, Hygrophila polysperma, Commelina benghalensis. The grasses are Elusine indica, Elytrophorus spicatus, Leptochloa chinensis, Panicum repens, Paspalidum flavidum, Setaria intermedia, Echinochloa crus-galli, Echinochloa colona, etc.

\subsection{Semi-Deep Water Ecology}

In this ecology, the standing water remain up to $50 \mathrm{~cm}$ throughout the crop season. So only aquatic/semiaquatic plants occur in this ecology. In this ecology, the paddy seeds were broadcasted before onset of monsoon, so after rain, weed seeds germinate quickly and grows faster than rice plants. But the diversity of species is very less. The common species in this ecology are Bergia capensis, Oxalis corniculata, Hydrocera triflora, Aeshynomene aspera, Aeshynomene indica, Sesbania bispinosa, Myriophyllum tetrandrum, Ludwigia adscendens, Trapa bispinosa, Enydra fluctuans, Sphenoclea zeylanica, Ipomoea aquatica, Hydrolea zeylanica, Limnophila aquatica, Limnophila heterophylla, Polygononum hydropiper, Alternanthera philoxeroide, Alternanthera sessilis, Ottelia alsimoides, Monochoria hastata, Typha elephantiana, Typha angustata, Limnophyton trifolia, Limnophyton obtusifolia, Potamogetum pectnatus, Potamogetum nodosus. The sedges and grasses are Schoenoplectus articulatus, Cyperus iria, Cyperus platistylis, Cyperus corymbosus, Echinocloa crusgalli, Echinochloa stagnina, Leersia hexandra, Panicum paludosum, Sacciolepis indica, Eriochloa procera, Oryza rufipogon, etc.

\subsection{Deep Water Ecology}

In deep water ecology, standing water remains above $50 \mathrm{~cm}$. through out crop season. After the field was dried, boro rice crop was grown. The species diversity was still less than semi deepwater. The floating plant and emergent types were met with in this ecology. The common species are Nymphaea nouchali, Nymphaea stellata, Nelumbo nucifera, Neptunia oleracea, Nymphoides indica, Nymphoides hydrophylla, Utricularia stellaris, Blyxa echinosperma, Ceratophyllum demersum, Nechamandra alternifolia, Vallisnaria spiralis. Pistia stratiotes, Spirodela polyrrhiza, Wolffia globosa, Azolla pinnata, Oryza rufipogon, Eichhornia crassipes, Leersia hexandra, Utricularia inflexavar stellaris.

\section{Conservation}

Every plant has theraptical value so weeds are not exception. Weeds have many utilitarian values such as medicinal, food, fodder, ritual purpose and soil conservation, etc. The species viz., Enydra fluctuans, Hydrolea zeylanica, Monochoria vaginalis, Limnophila indica, Nelumbo nucifera, Neptunia oleracea, Nymphaea nouchali, Pistia stratiotes, Trapa natans var. bispinosa, etc. are having medicinal properties for different diseases. Oudhia (2001) reported many medicinal weeds from Chhatisgarh. The species such as Alternanthera sessilis, Centella asiatica, Commelina benghalensis, Ipomoea aquatic, Portulaca oleracea, Mollugo pentaphylla and Marsilia minuta, etc. are used as leafy vegetable but the rhizome of Nelumbo nucifera, Trapa bispinosa var. bispinosa, etc. are used as food. The grasses like Panicum repens, Cynodon dactylon, Paspalum flavidum, Digitaria cliaris, Eriochloa procera, Chloris barbata, etc. are used as fodder. Azolla pinnata is very good fodder for cattle. Similarly Wolffia globosa is used as feed of duck and fishes. The species like Cynodon dactylon is used in every 
ritual of local people. Rice ecologies have been destroyed due to habitat destruction, construction of houses and conversion of rice field for other purposes so the flora in general and economic plants in particular are on the verge of extinction. It is high time to conserve all the useful weed species as species cafeteria/weed garden so that awareness will be developed among the common people about the utilitarian value of weed species.

\section{References}

Bahar, S. W. N., \& Bhat, G. A. (2012). Taxocoenosis and distribution of weed flora in the rice field monoculture of Kasmir valley (J and K) India. Inter. Journ. Botany, 8(2), 73-78. http://dx.doi.org/10.3923/ijb.2012.73.78

Bentham, G., \& Hooker, J. D. (1882-1883). Genera Plantarum (3 volumes). London.

Haines, H. H. (1921-1925). The Botany of Bihar and Orissa (6-parts). London.

Jain, S. K., \& Rao, R. R. (1977). A handbook of field and herbarium methods. Todays and Tomorrows Printers and Publishers, New Delhi.

Kunmar, G. S., Rajaratan, A., Thavaprakash, N., Babu, C., \& Umasankar, R. (2008). Nitrogen use efficiency in rice (Oryza sativa) in systems of cultivation with varied $\mathrm{N}$ level under $\mathrm{N}$ tracer technique. Asian Joun. Agric. Res., 2, 37-40. http://dx.doi.org/10.3923/ajar.2008.37.40

Maiti, M. M., Mishra, G., \& Ghosh, R. B. (1983). Some new records of weeds from crop fields of Orissa. Journ. Econ. Tax. Bot., 4, 308-310.

Mishra, S., \& Choudhury, B. P. (1996). Rice fields flora of Bhubaneswar. Bio. Sci. Res. Bull., 12(2), 99-112.

Moody, K. (1989). Weeds reported in rice fields in South and South East Asia. International Rice Research Institute, Manila, Philippines.

Moody, K., \& Drost, D. C. (1983). The role of cropping systems in weedsin rice. Weed control in rice (pp. 73-88). International Rice Research Institute, Manila, Philippines.

Oudhia, P. (2001). Common rice weeds used for first aid by Chattisgarh farmers. Agric. Sci. Digest., 21, 273-274.

Patnaik, H. (1956). Some useful weeds in and around Cuttack. Journ. Bomb. Nat. Hist. Soc., 54, 141-152.

Pragada, P. M., \& Venkaaiah, M. (2012). Phytosociological attributes of weed flora in major crops of North coastal Andhrapradesh, India. Pak. Journ. Weed Sci. Res., 18(1), 107-126.

Pragada, P. M., \& Venkaiah, M. (2010). Phytosociological attributes of weeds in rice fields of North coastal Andhra Pradesh, India. International Journ. of Curr. Res., 7, 1-4.

Saxena, H. O., \& Brahmam, M. (1994-1996). Flora of Orissa (Vols. 1-4). Regional Research Laboratory and Forest Development Corporation, Govt. of Orissa, Bhubaneswar.

Singh, D. J. C., \& Rao, K. N. (1973). Weed flora of Andhrapradesh. Proc. National Academy of Sciences, 19(2), 223-229.

Subudhi, H. N., \& Coudhury, B. P. (2000). Vegetation of rice fields in Cuttack districts (Orissa). Jour. Econ. Tax. Bot., 24(1), 157-159.

Subudhi, H. N., Panda, S. P., Naik, R. K., \& Choudhury, B. P. (2002). Weed flora of deep water rice fields in Orissa. Pl. Sci. Res., 24(1\&2), 50-52.

Tripathy, G., \& Mishra, G. (1988). Studies on the weed flora associated with wheat crops. Ind. Bot. Soc., 67, 227-228. 


\section{Appendix}

Appendix 1. Enumeration

Nymphaeaceae

Nymphaea nouchali Burm.f.

Nymphaea pubescens Willd.

Nelumbonaceae

Nelumbo nucifera Gaertn.

Papaveraceae

Argemone mexicana $\mathrm{L}$.

Capparaceae

Cleome gynandra $\mathrm{L}$.

Cleome monophylla $\mathrm{L}$.

Cleome rutidosperma Roxb.

Cleome viscosa $\mathrm{L}$.

\section{Violaceae}

Hybanthus enneaspermus (L.) Muell.

\section{Polygalaceae}

Polygala arvensis Willd.

Polycarpaea corymbosa (L.) Lamk.

Polycarpon prostratum (Forsk.) Asch. \& Sch.

\section{Portulacaceae}

Portulaca oleracea $\mathrm{L}$.

Portulaca quadrifida $\mathrm{L}$.

\section{Elatinaceae}

Bergia ammannioides Roxb.

Bergia capensis L.

Hypericaceae

Hypericum jopinicum Thunb. exMurry

Sterculiaceae

Melochia corchorifolia L.

\section{Zygophyllaceae}

Tribulus terrestris L.

\section{Oxalidaceae}

Biophytum sensitivum (L.) DC.

Oxalis corniculata L.

\section{Balsaminaceae}

Hydrocera triflora (L.) Wt. \&Arn.

\section{Fabaceae}

Aeschynomene indica $\mathrm{L}$.

Aeschynomene aspera $\mathrm{L}$.

Aeschynomene americana

Alysicarpus monilifer (L.) DC.
Alysicarpus vaginalis (L.) DC.

Crotalaria prostrata Rottl. exWilld.

Crotalaria quinquefolia $\mathrm{L}$.

Desmodium triflorum (L.) DC.

Indigofera linnaei Ali

Indigofera glabra $\mathrm{L}$.

Melilotus indica (L.) All

Sesbania bispinosa (Jacq.) Wt.\&Arn.

Smithia conferta Smith

Smithia sensitiva Ait.

Vigna trilobata (L.) Verd.

Vigna sublobata Ravi

Zornia gibbosa Span.

\section{Caesalpiniaceae}

Cassia mimosoides $\mathrm{L}$.

Cassia pumila Lam.

\section{Mimosaceae}

Mimosa pudica L.

Neptunia oleracea Lour.

\section{Droseraceae}

Drosera burmani Vahl

Drosera indica $\mathrm{L}$.

\section{Haloragaceae}

Myriophyllum tetrandrum Roxb.

Lythraceae

Ammannia baccifera $\mathrm{L}$.

Ammannia multiflora Roxb.

Rotala indica (Willd.) Koehne

\section{Onagraceae}

Ludwigia adscendens (L.) H. Hara

Ludwigia perennis $\mathrm{L}$.

\section{Trapaceae}

Trapa natans L. var. bispinosa (Roxb.) Makino

\section{Aizoaceae}

Glinus lotoides L.

Glinus oppositifolius (L.) DC.

Mollugo pentaphylla $\mathrm{L}$.

Apiaceae

Centella asiatica (L.) Urb.

Rubiaceae 
Dentella repens (L.) Forst. et Forst.

Hedyotis brachiata Wt. \&Arn.

Hedyotis corymbosa (L.) Lamk.

Spermacoce articularis L.f.

Spermacoce pusilla Wall.

\section{Asteraceae}

Ageratum conyzoides L.

Blumea membranacea DC.

Eclipta prostrata (L.) L.

Emilia sonchifolia (L.) DC. ex Wt.

Enydra fluctuans Lour.

Gnaphalium polycaulon Pers.

Grangea maderaspatana (L.) Lour.

Mikania cordata (Burm.f.) Robinson

Sphaeranthus indicus L.

Tridax procumbens L.

Vernonia cinerea (L.) Less.

\section{Sphenocleaceae}

Sphenoclea zeylanica Gaertn.

\section{Gentianaceae}

Canscora decussata (Roxb.) Sch. \& Sch.

Canscora diffusa (Vahl) R. Br.

Hoppea dichotoma Willd.

\section{Menyanthaceae}

Nymphoides hydrophylla (Lour.) Kuntze

Nymphoides indicum (L.) Kuntze

Hydrophyllaceae

Hydrolea zeylanica (L.) Vahl.

\section{Boraginaceae}

Coldenia procumbens L.

Heliotropium indicum L.

Heliotropium strigosum Willd.

\section{Convolvulaceae}

Ipomoea aquatic Forssk.

Ipomoea cymosa (Desr.) Roem. \& Sch.

Merremia tridentata (L.) Hall. f.

\section{Solanaceae}

Solanum surattense Burm. f.

\section{Scrophulariaceae}

Bacopa monnieri (L.) Pennell.

Centranthera tranquebarica (Sperigl.) Merr

Dopatrium junceum (Roxb.) Buch-Ham. exBenth.
Limnophila aquatica (Roxb.) Alston

Limnophila heterophylla (Roxb.) Benth.

Limnophila indica (L.) Druce

Lindernia anagallis (Burm.f.) Pennel

Lindernia crustacea (L.) Muell.

Lindernia viscosa (Horn) Bold

Mecardonia procumbens (Mills.) Small

Scoparia dulcis L.

\section{Lentibulariaceae}

Utricularia inflexaForssk. var. stellaris (L.f.) P.Taylor

\section{Acanthaceae}

Hygrophila auriculata (Schum.) Haine

Hygrophila polysperma (Roxb.) Anders.

Justicia betonica L.

Justicia diffusa Willd.

Lippia geminata Roxb.

Rungia pectinata (L.) Nees

Rungia repens (L.) Nees

Phyla nudiflora (L.) Rich

Nyctaginaceae

Boerhavia diffusa L.

\section{Amaranthaceae}

Achyranthes aspera L.

Aerva lanata (L.) Juss ex Sch.

Alternanthera philoxeroides (Mart) Griseb.

Alternanthera sessilis (L.) R. Br. ex DC.

Celosia argentea $\mathrm{L}$.

Gomphrena celosoides L.

\section{Polygonaceae}

Polygonum hydropiper L.

Polygonum plebeium R. Br.

\section{Euphorbiaceae}

Crozophora rottleri (Geisel) Juss

Croton bonplandianum Baill

Euphorbia hirta L.

Euphorbia rosea Retz.

Phyllanthus urinaria L.

Sebastiania chaemaelea (L.) Muell.

\section{Urticaceae}

Pilea microphylla (L.) Liebr

Pouzolzia indica (L.) Benn

Ceratophyllaceae 
Ceratophyllum demersum L.

\section{Hydrocharitaceae}

Blyxa echinosperma ( Clarke) Hook.f.

Hydrilla verticillata (L.f.) Royle

Nechamandra alternifolia (Roxb.) Thw.

Ottelia alismoides (L.) Pers.

Vallisneria natans (Lour.) H. Hara

\section{Orchidaceae}

Spiranthes sinensis (Pers.) Ames

Zeuxine strateumatica (L.) Schltr.

\section{Amaryllidaceae}

Crinum defixum Ker-Gawl.

Crinum latifolium L.

Curculigo orchioides Gaertn.

\section{Pontederiaceae}

Eichhornia crassipes (Mart.) Solm-Laub.

Monochoria hastata (L.) Solm.

Monochoria vaginalis (Burm.f.) Presl. ex Kunth.

\section{Xyridaceae}

Xyris indica L.

\section{Commelinaceae}

Commelina benghalensis L.

Murdannia nudiflora (L.) Brenan

Amiscophacelus axillaris Rao \& Kamathy

Typhaceae

Typha angustata Bory\&Chaub.

Typha elephantiana Roxb.

\section{Araceae}

Pistia stratiotes L.

\section{Lemnaceae}

Spirodela polyrrhiza (L.) Schleid.

Wolffia globosa (Roxb.) Hartog\& Vander Plas

\section{Alismataceae}

Limnophyton obtusifolium (L.) Miq.

Sagittaria guayanensis HBK

Sagittaria trifolia L.

\section{Najadaceae}

Najas faveolata A. Br. ex Magam.

\section{Aponogetonaceae}

Potamogeton nodosus Poir.

Potamogeton pectinatus L.

\section{Eriocaulaceae}

Eriocaulon quinquangulare L.

\section{Cyperaceae}

Bulbostylis barbata (Roxb.) Kunth

Cyperus castaneus Willd.

Cyperus cephalotes Vahl

Cyperus compressus L.

Cyperus difformis L.

Cyperus esculentus L.

Cyperus iria L.

Cyperus platystylis $\mathrm{R}$. Br.

Cyperus rotundus L.

Eleocharis acutangula (Roxb.) Schutt.

Eleocharis dulcis ( Burm.f.) Henschel

Fimbristylis dichotoma (L.) Vahl

Fimbristylis ovata (Burm.f.) Kern

Fimbristylis schoenoides (Retz.) Vahl

Fuirena ciliaris (L.) Roxb.

Schoenoplectus articulatus (L.) Palla

\section{Poaceae}

Brachiaria ramosa (L.) Stapf.

Brachiaria reptans (L.) GardetHubb

Chloris barbata $\mathrm{Sw}$.

Chrysopogon aciculatus (Retz.) Trin

Cynodon dactylon (L.) Pers.

Dactyloctenium eagyptium (L.) Beauv.

Dicanthium pertusum (L.) Clayton

Digitaria ciliaris (Retz.) Koel

Echinochloa colonum (L.) Link

Echinochloa crusgalli (L.) Beauv.

Echinochloa stagnina (Retz.) Beauv.

Eleusine indica (L.) Gaertn.

Elytrophorus spicatus (Willd.) A. Camus

Eragrostis ciliaris (L.) R. Br.

Eragrostis japonica (Thunb.) Trin.

Eriochloa procera (Retz.) Hubb

Imperata cylindrica (L.) Rauch

Isachne globosa (Thunb.) Kuntze

Leersia hexandra Sw.

Leptochloa chinensis (L.) Nees

Oplismenus compositus (L.) Beauv.

Oryza rufipogon Griff.

Oryza nivara Sharma etShastry 
Panicum paludosum Roxb.

Panicum repens $\mathrm{L}$.

Paspalidium flavidum (Retz.) A. Camus

Perotis indica (L.) Kuntze

Rottboellia co chinchinensis (Lour.) Clayton

Sacciolepis indica (L.) A. Chase

Setaria intermedia (Roth) Roem\& Sch.

Sporobolus indicus (L.) R. Br.

Vetiveria zizanioides (L.) Nash

Azollaceae

Azolla pinnata $\mathrm{R}$. Br.

Parkeriaceae

Ceratopteris thalictroides (L.) Brongn

\section{Marsiliaceae}

Marsilia minuta L.

\section{Copyrights}

Copyright for this article is retained by the author(s), with first publication rights granted to the journal.

This is an open-access article distributed under the terms and conditions of the Creative Commons Attribution license (http://creativecommons.org/licenses/by/3.0/). 